\title{
Knowledge Transfer: Exchanging Knowledge with the Field
}

\author{
By Gemma John (University of Manchester)
}

Contributors to this special issue of Anthropology Matters frame the relationship between a field researcher and the people he or she meets whilst conducting fieldwork in terms of the exchange of knowledge. As the field researcher immerses him or herself in fieldwork, this involves getting to know those he or she meets intimately, as well as them getting to know the researcher. Yet, 'the field' is not only a site in which knowledge is exchanged between the field researcher and the people he or she meets as part of fieldwork, but has also become one of a number of potential sites in which knowledge is created and 'expertise' can be located. Nowotny (2001) explains that 'expertise' no longer appears as a quality located in specific institutions, such as the university, and specific people, such as academics, but is distributed between an array of institutions and people. 'Knowledge transfer' concerns the way in which these sites are joined in novel ways, to meet consumer demand (Gibbons 1994). Contributors, then, also frame 'the field' as a site of expertise, and knowledge transfer as the practical problem of exchanging knowledge between people in 'the field' and the field researcher so that each might benefit from the others' expertise. However, such a transfer, as we learn from the Contributors, is not always straightforward.

First, knowledge is negotiated: knowledge transfer is not simply a matter of its smooth transfer from one person to the next, through space and time, but knowledge is selected and translated and reconfigured as it passes between people. What starts off as knowledge might end up as something quite different - non-knowledge - in the form of lies, gossip, and mistruth. Second, knowledge can be arrested: there are points when knowledge does not flow. Knowledge sometimes does not flow when worlds, contexts and people intersect, and can become transmuted in the process of being transferred. Third, knowledge can take a variety of forms. It might be transferred as narrative, stories, and spoken word, in the form of gesture, technique, and practical work, or in the form of emotions, touch and visual depictions. The form that knowledge takes, Contributors argue, often determines what does or does not count as knowledge, and therefore what we come to know. Certain interests arise out of their articles, gathered together in the issue into three sections. I turn to these sections below.

\section{Contested knowledge}

When 'expertise' is distributed, there appear multiple locations in which knowledge can be located. The question arises - what is knowledge? This question is also at the heart of fieldwork research. Contributors to this volume consider knowledge as carefully, sometimes passionately, debated amongst their fieldwork interlocutors. What emerges as recognisable knowledge, they argue, emerges out of these debates. 
Writing about the claims and counter-claims made by actors on either side of the Genetic modification debate, Downing argues in this section whether recognising knowledge as such by those who receive it depends on the very way in which it is relayed. Here, knowledge takes the form of a story or narrative, and it is the way in which people - those employed in 'local food networks' in South West England convince others of their story that determines what is or is not recognised as knowledge. Downing argues such findings reveal the process of fieldwork itself as one of persuasion - ethnographic 'reality' is the result of field researchers being persuaded by the people they meet in the field about what and what not to record as knowledge.

Also in this section, Shapiro examines how knowledge is the result of the way in which truth and lies are interwoven. His article focuses on a particular neighbourhood in North East Brazil. He argues that, whilst fieldwork is a process of 'sharing truthful information', what actually gets shared between field research participants and the field researcher is often far from being the truth. He argues that '...narrative is constituted by successfully omitting and occluding some facts just as much as it is by revealing others'. Again, Shapiro argues, this raises problems for the field researcher as he or she must establish what is truth or lies in constructing a particular description of 'the field'.

In his article, Allen does not focus on narrative, story-telling, or the spoken word, but on the way in which knowledge is performed. In this contribution, he focuses on the activities of elderly women who travel to India to be trained in the maintenance and repair of solar photovoltaic technologies. Here, knowledge is sustained through doing - that is, it is through the ongoing alignment of objects and symbols, gestures and bodies that these women (who do not have a common language) share what they know. What happens when people stop doing, stop enacting their knowledge, he asks? In the case of the women described by Allen, knowledge is lost.

\section{Arrested Knowledge}

Contributors also describe the way in which knowledge is sometimes not transferred. Some articles discuss how knowledge does not flow because it is caught at the intersections between different worlds, different contexts, and different people.

These intersections are something that the field researcher must learn to negotiate as part of fieldwork, Morreira argues in this section. In her article on forced migration between Zimbabwe and South Africa and human rights violations, she writes '[when we] feel discomforted, we know that our fieldwork is going well because we are learning to walk between worlds'. Focussing on the difficulties of translating people's experiences of human rights violations in terms of legal and anthropological knowledge, Morreira comments that sometimes knowledge cannot be translated across disciplinary and cultural boundaries, thus rendering communication across these boundaries problematic.

As Corsin Jimenez highlights, such intersections also make visible the stuff of which knowledge transfer is made: social relations. Knowing often requires the acknowledgements of from whom, what, and when knowledge comes. As he 
comments, 'relational acknowledgements' are part of recognising and transferring what you know. In a similar vein, Mateos Cortes writes knowledge is the outcome of what she describes as a 'relational' process of transferral and exchange. She focuses on the way in which discourse on 'interculturality' developed in Europe is transferred to different kinds of Mexican actors. In her description of this transfer, Mateos Cortes states it is important to note the way in which the knowledge that is transferred is translated, transmuted and transfigured in relation to the institutions, people, and contexts it flows between.

Konopinski writes about the research proposal writing process, and the difficulties of transferring knowledge from those who produce it (academics) to those who are meant to consume it (non-academics). She notes academics have to take into account the interests of non-academics when constructing a research proposal. Knowledge transfer, here, appears achieved by acknowledging - from the very start - the social relations that non-academic 'users' consider important as a means of getting knowledge to flow between the two groups.

\section{Embodied Knowledge}

The last section in this special issue focuses on the way in which knowledge might flow: knowledge might take the form of words (written or spoken), or take another form - appear embodied in bodily gestures, senses, and material things. Contributors to this section imply that the form that knowledge takes shapes our perceptions of knowledge, and therefore what we come to know.

In this section, Blake focuses on touch as a medium of knowledge transfer. Writing about the experiences of children in an oncology ward in South Africa, she argues touch is often not recognised as form of knowledge. Yet, field researchers often engage in physical contact with their field interlocutors. Blake notes, '....engaging in physical contact with one's research subjects changes the dynamic between researcher and participant as well as what the researcher comes to know about those they are studying'.

Hingley makes a similar point. She compares the participant observation field research she conducted in Paris during which she took written field notes, with the fieldwork she conducted in Birmingham during which she took photographs. A documentary photographer by training, and now a social anthropologist, she argues that '...in the same way that a photographer decides on the lines which frame and limit the scene of their image', field researchers construct their subjects of study by the way in which they write about them. She concludes, when conducting fieldwork, researchers must remain aware of the limits of both visual and textual ways of knowing.

Writing about the use of materials libraries to facilitate the transfer of knowledge about material things between those who produce and use them, Wilkes notes the transfer of knowledge via these material things often makes less (rather than more) clear the knowledge that is to be conveyed. In other words, material things are used differently as a consequence of the different ways in which they are interpreted, and 
as they are used differently these different interpretations are conveyed to others. Wilkes notes, '[k]nowledge is thought to be inherent in some materials and cannot always be controlled by manufacturers, despite their best efforts.'

\section{Returning to Knowledge Transfer}

Contributors to this special issue of Anthropology Matters explore knowledge transfer in its widest possible sense. In thinking as widely and creatively as they can about knowledge exchange, they investigate the ways in which knowledge is transferred both within and outwith academic settings. They focus on knowledge transfer in relation to collaborative research projects in the UK, forced migration between Zimbabwe and South Africa, the genetic modification debate in South West England, lies and gossip in South East Brazil, the repair of solar photovoltaic technologies in India, 'interculturality' in Mexico, materials libraries in the UK, touch in a South African oncology ward, and photographic documentary making in Birmingham. Their articles examine the different kinds of knowledge transferred and the kinds of institutions and people engaged in its transfer. They also examine the different forms that knowledge might take.

This issue is split into three sections. Each section features three articles written by postgraduate and early career scholars, followed by a comment from a senior scholar on how the articles work together and how they address the theme of this issue. It is not important to read the issue as a whole. Rather, I encourage readers to dip in and out of it. I ask readers to reflect on what insights the articles bring to the formal 'knowledge transfer' activities now held to be an important part of academic life.

September 2011

Gemma John

\section{About the Author}

Gemma John is currently a postdoctoral research associate at the Centre for Research on Socio-Cultural Change (CRESC) at Manchester University. She was awarded her doctorate in 2009 from St Andrews University, and has subsequently held a post doctoral research fellowship at Edinburgh University, and has taught at St Andrews, Edinburgh and lectured at Manchester University. Her doctoral research focuses on personhood as it is expressed through the implementation, reception, and use of Freedom of Information legislation in Scotland. She is interested in constitutional reform, including devolved government in the form of access to information legislation, and now the notion of responsibility as embodied in the Big Society initiatives. 


\section{Bibliography}

Gibbons, M. et al (1994), The New Production of Knowledge: the Dynamics of Science and Research in Contemporary Societies, Sage

Nowotny, H. et al (2001), Re-thinking Science:

Knowledge and the Public in an Age of Uncertainty, Wiley-Blackwell 